Проданик В. М., к.держ.упр., ПрАТ «ВНЗ «Міжрегіональна Академія управління персоналом», м. Київ, ORCID: 0000-0002-3112-479X,

Шинкарьов А. М., к.держ.упр., ПрАТ «ВНЗ «Міжрегіональна Академія управління персоналом», м. Киї, ORCID: 0000-0002-3501-0116

Prodanyk V., Candidate of State Administration, Associate Professor of the Department of Public Administration of the Educational and Scientific Institute of International Relations and Social Sciences, PJSC "Higher Educational Institution" Interregional Academy of Personnel Management ", Kyiv,

Shinkaryov A., Candidate of State Administration, Associate Professor of the Department of Public Administration of the Educational and Scientific Institute of International Relations and Social Sciences, PJSC "Higher Educational Institution" Interregional Academy of Personnel Management ", Kyiv

\title{
СТРАТЕГІЧНЕ ПЛАНУВАННЯ РОЗВИТКУ РЕГІОНІВ ЯК ОРГАНІЗА- ЦІЙНИЙ МЕХАНІЗМ ПУБЛІЧНОГО УПРАВЛІННЯ
}

\section{STRATEGIC PLANNING OF REGIONAL DEVELOPMENT AS AN OR- GANIZATIONAL MECHANISM OF PUBLIC GOVERNANCE}

Наразі в Украӥні відбувається процес формування нової державної регіональноі політики, зокрема на засадах використання саме механізмів публічного управління та законодавчого ії забезпечення. Метою такого формування є створення умов для поліпшення якості життя людини, додержання гарантованих державою соиіальних стандартів для кожного громадянина незалежно від його місия проживання, через забезпечення територіально иілісного та збалансованого розвитку України, інтеграиії регіонів в єдиний економічний, політичний, правовий, інформаційний та культурний простір, максимально повного використання їх потенціалу з урахуванням природних, політичних, історичних, культурних, сочіальних і інших особливостей, підвищення конкурентоспроможності регіонів і реалізаиії дієвого самоуправління.

У статті обтрунтовано, що ефективний розвиток неможливо здійснити без реальної децентралізації, зміџнення самоврядування в Україні та залучення територіальних громад до формування, впровадження політики (стратегічного бачення) регіонального розвитку.

Державна стратегія регіонального розвитку на 2021-2027 роки, яка затверджена постановою Кабінету Міністрів України від 5 серпня 2020 р. № 695 є основним планувальним документом для реалізачії секторальних стратегій розвитку, координачії державної політики в різних сферах, досягнення ефективності використання державних ресурсів у територіальних громадах і регіонах в інтересах людини, єдності держави, сталого розвитку історичних населених місиь та збереження 152 
традииійного характеру історичного середовища, збереження навколишнього природного середовища та сталого використання природних ресурсів для нинішнього та майбутніх поколінь украӥнців [1].

Доведено, щзо найбільш суттєвими викликами, на які держава має реагувати иляхом вироблення та реалізаџії державної регіональної політики, $\epsilon$ неспроможність більшості територіальних громад самостійно вирішувати питання, віднесені до їх повноважень. В цілому, передавати повноваження та відповідальність за регіональний розвиток на органи місчевого самоврядування не можна допоки не буде створена дієва $і$ ефективна система місиевого самоврядування $i$, y периу чергу, дійсно спроможна та економічно стійка територіальна громада.

Ключові слова: публічне управління та адміністрування, стратегічне планування, органи влади, регіональний розвиток.

Currently, Ukraine is in the process of forming a new state regional policy, in particular on the basis of the use of public administration mechanisms and its legislative support. The purpose of such formation is to create conditions for improving the quality of human life, observance of state-guaranteed social standards for every citizen regardless of his place of residence, through ensuring territorially integrated and balanced development of Ukraine, integration of regions into a single economic, political, legal, informational and cultural space. maximizing the use of their potential, taking into account natural, political, historical, cultural, social and other features, increasing the competitiveness of regions and the implementation of effective self-government.

The article substantiates that effective development is impossible without real decentralization, strengthening of self-government in Ukraine and involvement of territorial communities in the formation, implementation of policy (strategic vision) of regional development.

The State Strategy for Regional Development for 2021-2027, approved by the Cabinet of Ministers of Ukraine on August 5, 2020 № 695 is the main planning document for the implementation of sectoral development strategies, coordination of public policy in various areas, achieving efficient use of public resources in local communities and regions in the interests of man, the unity of the state, sustainable development of historic settlements and preservation of the traditional character of the historic environment, preservation of the natural environment and sustainable use of natural resources for present and future generations of Ukrainians [1].

It is proved that the most significant challenges to which the state must respond by developing and implementing state regional policy is the inability of the majority of territorial communities to independently resolve issues related to their powers. In general, the authority and responsibility for regional development cannot be transferred to local self-government bodies until an effective and efficient system of local self-government is created and, first of all, a truly capable and economically sustainable territorial community.

Key words: public administration, strategic planning, authorities, regional development. 
В цілому, під стратегічним плануванням доцільно розуміти особливий вид планової діяльності, що полягає в розробці стратегічних рішень (у формі прогнозів, проектів, програм і планів), які передбачають висування таких цілей, завдань і стратегій розвитку регіонів, реалізація яких забезпечить їх ефективне функціонування в довгостроковій перспективі та швидку адаптацію до умов зовнішнього середовища, що постійно змінюються.

Важливо, що стратегічне планування як функція управління полягає в намаганні завчасно врахувати при можливості всі внутрішні та зовнішні фактори, що забезпечують сприятливі умови для нормального функціонування і розвитку об'єкта управління. Планування - це визначення параметрів управлінського процесу на основі співставлення інформації про потреби зовнішнього середовища в результатах діяльності та його можливостей, з урахуванням розвитку самого суб'єкта, що направлено на досягнення поставленої перед системою мети, а план - це кількісне відображення цілей та розробка шляхів їх досягнення.

В роботі проаналізовано об'єктивний характер стратегічного планування, як частини публічного управління в розвинених державах світу, праці вітчизняних і зарубіжних науковців щодо проблем стратегічного управління регіонального розвитку та встановлено, що оптимальне сполучення стратегічного планування та публічного управління - реальний шлях розвитку соціальноекономічного потенціалу держави.

Відзначимо, що в процесі вдосконалення системи стратегічного планування на публічному рівні доцільно було б провести оптимізацію державних цільових програм, перейти від тактичного ситуативного планування до стратегічного планування, яке дає змогу розширити планові горизонти, комплексно вирішувати проблеми публічного управління. Саме завдяки вмілому поєднанню зазначених факторів реформування системи стратегічного планування розвитку регіонів в публічному управлінні можна досягти головної мети - створення ефективних і реальних стратегічних програм розвитку держави та окремих регіонів.

Важливо, що в статті сформульоване категорію організаційного механізму регіонального розвитку за сучасних умов подальшого реформування системи публічного управління в Україні та децентралізації владних повноважень.

Аналіз останніх досліджень і публікацій. Слід визначити, що певні проблеми управлінської теорії та стратегічного підходу в науковій літературі опрацьовано досить широко (теоретичний аспект у роботах М. Паркер Фоллет, Р. Стогділлі, М. Мескона та Ф. Хедоурі, Г. Кунца, Д. Занда та інших, науковометодичний аспект у працях I. Ансоффа, Т. Пітерса, М. Портера, В. Кнорінга та інших), то питання практичного застосування стратегічного підходу опрацьовано значно менше. В літературі вони представлені уривчасто та стосуються 
лише окремих проблем у працях 3 державного управління та регулювання. Важливі аспекти теорії стратегічного управління в сфері регіонального та місцевого розвитку досліджували у своїх працях такі українські вчені, як О. Амосов, Т. Безверхнюк, О. Бобровська, В. Вакуленко, П. Волянський, В. Воротін, В. Геєць, С. Домбровська, Д. Дзвінчук, О. Коваль, А. Шевченко та ін.

В окремих сферах стратегій ресурсного забезпечення розвитку національних економік відомі праці О. Виханського, Р. Фатхутдінова, А. Бусигіна, В. Глухова, В. Попова, С. Ляпунова, Н. Архіпової, Б. Рапопорта, та інших, українських вчених Ф. Хміля, Є. Панеченка, Й. Лісова, В. Крутько, Л. Логіненко, В. Герасимчука, В. Бесєдіна, Л. Федулової та інших. Розробки організаційних механізмів у сфері публічного управління взагалі практично відсутні.

Крім того, зовсім невирішеними є суттєві питання розробки та функціонування організаційних механізмів державного регулювання в сфері стратегічного планування регіонального розвитку на засадах генезису ролі місцевого самоуправління, яке сьогодні виходить на перші роли в місцевому розвитку. Практично відсутні дослідження в сфері узагальнень світового досвіду використання організаційних механізмів взаємодії органів публічної влади з усіма суб'єктами господарської діяльності для вирішення низки стратегічних і оперативних проблем ресурсного забезпечення українських суб єктів господарювання.

Мета статті полягає в дослідженні та уточненні сутності окремих організаційних механізмів і інструментів стратегічного планування та визначення об'єктивних теоретичних законів і закономірностей в контексті сучасного етапу регіонального та місцевого розвитку в Україні.

Виклад основного матеріалу. Незважаючи на те, що від початку проведення стратегічних реформ децентралізації повноважень влади в сфері державного та регіонального управління та заявлених пріоритетів Уряду щодо реформування системи публічного управління, пройшло вже чимало часу, висвітлення в науковій літературі проблем організаційно-правових засад стратегічного управління та планування регіонального розвитку та модернізації самої системи (механізмів і інструментів) державного управління об'єктами регіонального та місцевого розвитку України в нових умовах є недостатнім.

На нашу думку, на регіональному та місцевому рівні організаційний механізм публічного управління - це сукупність інструментів, методів і форм впливу територіальних органів державної (виконавчої) влади та місцевого самоврядування на діяльність суб'єктів господарювання в інтересах певної громади.

Донедавна більшість стратегічних планів, які готувались для українських регіонів і субрегіонів у рамках програм міжнародної технічної допомоги так i залишились нереалізованими через відсутність фінансування проектів розвитку 3 державного бюджету, відсутність, чи майже незначні бюджети розвитку в мі- 
сцевих бюджетах та відсутність практики регіональної та місцевої влади шукати додаткові альтернативні джерела коштів. Ці зміни призвели до зростання асиметрії в регіональному розвитку та поширили розуміння необхідності подальших дій щодо вдосконалення чи нового формування всієї системи стратегічного планування в Україні.

Країни з різним рівнем розвитку ринкових відносин мають території, яким властиві суттєві відмінності розвитку та планування. Завдання державного стратегічного планування - забезпечити свої громадян рівними можливостями, гарантованими доступом до всіх послуг і зберегти єдність державного простору при регіональних і місцевих відмінностях. Як зовнішній фактор - необхідність узгодження власних економіко-організаційних механізмів із державними політиками регіонального розвитку європейських держав у рамках національних євроінтеграційних процесів, зокрема за умов продовження процесу децентралізації владних повноважень на регіональні та місцеві рівні.

В більшості країн з розвиненими ринковими відносинами теж існують певні диспропорції між окремими їх регіонами та субрегіонами. I це загалом раціонально, оскільки території, які більше заселені чи знаходяться біля узбережжя морів значно більше економічно спроможні, ніж гірські території або 3 меншим чисельністю населення.

Власне Європейський Союз і інші європейські держави приділяють дуже велику увагу регіональному розвитку та створенню умов для об'єднання європейських регіонів і формування потужних (згуртованих) регіонів. Такі стратегічні плани ставить перед собою уряди європейських країн, органи управління регіонів і субрегіонів. Окремим напрямом стратегічного сприймання розвитку є транскордонні регіоні та кластери, але це не входить в предмет нашої статті.

Відзначимо, що існують різні погляди на формування сучасного публічного управління та адміністрування в сфері регіонального та місцевого розвитку. Це, по-перше, сукупність наділених певною компетенцією та певним чином структурованих суб'єктів держави, діяльність яких спрямована на певні регіональні та місцеві об'єкти суспільства. По-друге, публічне управління - це розвинена система управлінських зв'язків, відносин і організації впливу суб'єкта та об'єкта. Вони мають вигляд каналів, по яких здійснюється комунікація, реалізується влада на різних рівнях. По-третє, публічне управління являє собою діяльність з іï сукупними механізмами забезпечення активності суб'єктів управління, що включає систему політичних, правових, організаційних, моральних норм, стратегій, процедур. Діяльність виступає одночасно основою технологізації публічного управління та його креативності. По-четверте, публічне управління виступає як сукупність управлінських функцій, пов'язаних з підтримкою рівноваги та розвитку суспільної системи, дотримання режиму 
законності, прав і свобод людей, надання суспільству різних послуг. По-п'яте, публічне управління немислиме без відповідних об'єктів. Ними виступають ті чи інші об'єкти держави або окремих регіонів, на які спрямовується компетенція суб'єктів державного управління і якими реалізується їх діяльність. Пошосте, публічне управління містить складну та суперечливу сукупність ідей, теорій, поглядів, що використовують суб'єкти управління для обгрунтування, побудови й реалізації управління. По-сьоме, публічне управління являє собою систему, що саморозвивається, найважливішою складовою якої $є$ система іiі відтворення [2].

Відзначимо, що публічне управління має свої специфічні теоретичні закони та закономірності, організаційні механізми та логіку функціонування, йому властива об'єктивно обумовлена ресурсна база та певна автономність в межах суспільного розвитку. В контексті державного стратегічного планування важливим $є$ розглянути процеси самоорганізації та самоврядування, що притаманні самій системі публічного управління як відкритій системі, зокрема за сучасних умов нового етапу децентралізації владних повноважень. Для неї характерною є здатність оновлення та адаптації до зміни зовнішнього середовища, аби ефективно продовжувати свій розвиток і функціонування за умов глибоких ринкових перетворень і оновлення організаційних механізмів розвитку, зокрема прийняття нового закону про місцеве самоврядування.

Окремий зв'язок здійснюється через недержавні інститути, політику держави, іiі зміну чи коригування i наступне приведення системи управління у відповідність $з$ новими завданнями. Уточнення законів і закономірностей господарського та соціального розвитку, оволодіння ефективними формами і механізмами діяльності з боку суб'єктів державного управління забезпечують алгоритм функціонування державного організму, адекватний загалом рівню розвитку окремої держави.

У методологічному значенні та контексті дослідження організаційних механізмів, закон у нашій статті розглядається як об'єктивний, істотний, необхідний, сталий зв'язок або відношення між явищами. Найсуттєвішою ознакою закону є те, що він відображає об'єктивний стан речей, об'єктивні зв'язки між речами, предметами, явищами. Іншою важливою ознакою закону $\epsilon$ необхідність такого зв'язку, що неминуче виявляється в процесі розвитку того чи іншого явища. Закон - це зв'язок між сутностями, який є: об'єктивним i необхідним; загальним і внутрішнім; суттєвим і повторювальним.

Будь-яка наука характеризується властивими тільки їй законами та закономірностями. У науці управління також є свої закони та закономірності. Об'єктивні теоретичні закони управління, на відміну від державних (правових) законів, що регулюють суспільні відносини, це описувані науковою теорією істотні, необхідні та повторювані загальні форми взаємозв'язків між керуючим 
суб'єктом і керованим об'єктом, між системою управління і соціальним середовищем. Закони управління виражають необхідність і загальність тих сторін, моментів управлінської діяльності і відносин, які історично складаються, закріплюються і відтворюються у структурі та функціях управління.

Закономірні (законом обумовлені) структурні та функціональні взаємозв'язки не діють з неминучістю, а реалізуються у вигляді тенденцій, що пробиваються через безліч конкретних явищ і обставин, індивідуальних актів поведінки і дій, що підкоряються імовірнісним «правил гри». Реалізація законів залежить від багатьох умов (змінних), але, перш за все від керуючого суб'єкта, його знань, здібностей, але також і від керованого об'єкта [3].

Роль законів управління виражається в тому, що вони: утворюють теоретичний фундамент галузі управління; сприяють переходу емпіричного підходу до професійного; дозволяють правильно оцінити виникаючу ситуацію; дозволяють аналізувати зарубіжний досвід; виражають якісні властивості і зв'язки процесів і явищ, що характеризують відносини управління та напрямки їх розвитку. Закони управління виявляють свої вимоги в реалізації принципів управління, функціональному розподілі праці, структурі системи управління, у механізмі та методах управління; в процесі управління.

У наукових дослідженнях управління склалася парадоксальна ситуація: починаючи з 90-х років минулого століття, проблеми законів і закономірностей управління не розглядаються. Це викликається складнощами перехідного періоду, зокрема в сфері суспільних наук [4].

Науковці публічного управління вважають, що закони та закономірності управління відображають найбільш важливі, необхідні, сталі та повторювані зв’язки явищ i процесів, які допомагають розкрити їх природу, сутність та внутрішній зміст. Закони та закономірності публічного управління розглядаються нерідко як одне поняття, зважаючи на те, що між ними є багато спільного: по-перше, вони носять об'єктивний характер; по-друге, формулюються на підставі розкриття відносин як між суб'єктом і об’єктом управління, так і внутрішніх, притаманних кожному з них, а також зв'язків із зовнішнім середовищем. На нашу думку ці явища мають суттєві відрізнення, оскільки закони діють постійно на відміну від закономірностей, які тільки певний час актуальні.

У сфері публічного управління виділяють такі основні закони як: єдності системи управління, пропорційності суб’єкта та об’єкта управління, поєднання централізації та децентралізації, співвідносності керуючої та керованої систем [5].

Слід розрізняти поняття закону i закономірностей. Закономірність - це термін, який відображає стан речей, що об'єктивно існує в реальному світі (закономірності взаємодії небесних тіл, хімічних речовин, соціальних спіль- 
нот, управлінських структур). Їх пізнання та узагальнення $є$ підставою для формулювання законів як обов'язкової складової будь-якої наукової теорії. Закони управління відображають найбільш суттєві, необхідні, сталі та повторювані зв’язки між елементами системи та учасниками процесів іi функціонування та розвитку, що допомагають розкрити їхню природу та внутрішній зміст. Системи управління є відкритими, значний вплив на їх стан справляють фактори зовнішнього оточення.

Відзначимо, що стратегічне планування є основою всіх життєдіяльних процесів розвитку держави та їі територій, важливим етапом процесу управління, що визначає цілі, ефективні методи, засоби, необхідні для досягнення цілей, систему показників, визначаючих вектор розвитку та хід робіт з досягнення поставлених завдань.

Для успіху стратегічного планування необхідна згода усіх зацікавлених сторін щодо довготермінової мети (цілі) та чітких термінів виконання завдань і пріоритетів щодо узгоджених завдань розвитку. Також кожна стратегія має бути інтегрована до бюджетного процесу, що забезпечить відповідність запланованих заходів, які спрямовані на досягнення результату в рамках наявних фінансових ресурсів.

По змісту стратегічне планування - це вибір цілей і орієнтирів, визначення стратегіі ( напряму) розвитку, що забезпечать ефективність державного управління, розвитку країни. Специфіка стратегічного планування як процесу полягає в тому, що однією з його важливих завдань є зменшення невизначеності майбутнього, але це не повинно перетворитись на «пусті бажання чи обіцянки».

Відзначимо, що стратегічне планування являє собою цілісну ієрархічну систему. Методологічною основою дослідження закономірностей регіонального стратегічного планування може бути також кібернетичний підхід, але це теж не є предметом нашої статті.

Багато держав щороку розробляють національні програми реформ чи модернізації управління, що визначає конкретні політики та заходи в різних суспільних сферах для досягнення цілей, а також програми стабілізації, що містять бюджетний прогноз і план на наступні 3-4 роки. В Україні подібні довгострокові стратегічні документи також розроблялися протягом багатьох років. Таким документом була Стратегія економічного та соціального розвитку України “Шляхом європейської інтеграції” на 2004-2015 рр. Після зміни політичної влади в 2005 році уряди не використовували іiі в своїй діяльності, а згодом вона втратила чинність. Таких прикладів багато, але існує і позитивна практика стратегічного планування розвитку. Як приклад - це регіональні стратегії розвитку, яку вдало були реалізовані в системі державного та регіонального розвитку. 
Отже, для України запровадження європейської практики розробки стратегічних документів видається вкрай необхідним, оскільки це дає загальне бачення майбутнього та основу для розробки на середньострокову перспективу більш конкретних стратегічних документів. Відсутність чітко окресленого цілісного образу майбутнього можна вважати однією з основних причин того, що Україна вже майже 30 років незалежності знаходиться у перехідному стані та поки що не посіла гідного місця в світовій спільноті країн з розвиненими ринковими відносинами.

У цілому, середньострокове стратегічне планування здійснюється відповідно до Закону України "Про державне прогнозування та розроблення програм економічного і соціального розвитку", який встановлює загальні механізми (економіко-організаційні) і порядок розроблення, затвердження та виконання прогнозних і програмних документів економічного та соціального розвитку, а також права та відповідальність суб'єктів державного управління учасників у сфері розроблення програм економічного і соціального розвитку. Раніше цим займався також Національний інститут стратегічних досліджень, але сьогодні він дуже слабкий для цього.

Означений документ передбачає, що базою середньострокового стратегічного планування $\epsilon$ прогнозування, що визначається як науково обгрунтоване передбачення напрямів розвитку господарського комплексу, окремих галузей економіки або окремих адміністративно-територіальних одиниць, можливого стану економіки та соціальної сфери в майбутньому, а також альтернативних шляхів і строків досягнення параметрів економічного і соціального розвитку [6].

Сучасна система стратегічного планування в Україні передбачає також розробку документів галузевого рівня - загальнодержавних програм економічного, соціального розвитку, інших державних цільових програм. До недавнього часу існувало близько 300 офіційно затверджених галузевих стратегій, концепцій, програм, які за видатками на своє виконання у розрізі одного року в декілька разів перевищували видаткову частину державного бюджету. При цьому відсутній механізм узгодження цих галузевих документів між собою, їх підпорядкування цілям урядової програми або іншого загального стратегічного документу на середньостроковий період. До 2012 р. ст. 8 Закону України "Про державне прогнозування та розроблення програм економічного і соціального розвитку України" передбачала, що відповідно до Програми діяльності Кабінету Міністрів України та стратегій, концепцій, програм галузевого рівня, короткострокові цілі та пріоритети повинні щорічно визначатися у Державній програмі економічного і соціального розвитку України, а останній документ, у свою чергу, мав бути основою Державного бюджету України на відповідний рік.

Таким чином, на даний час систему стратегічного планування в Україні 
не можна вважати цілісною та логічно завершеною. Можливі різні варіанти іiі удосконалення та подальшого формування. В Україні поки що не вдалося побудувати функціонально ефективної та структурно злагодженої системи державного управління, в якій, зокрема, бракує цілісного стратегічного планування на вищому рівні. Воно є особливо важливим, оскільки в іншому разі під впливом зовнішніх чинників перед органами державного управління ставляться невизначені до кінця завдання, а подекуди - нездійсненні цілі, поставлені політиками.

Відсутність чітко визначених стратегічних цілей, пріоритетних напрямів і завдань соціально-економічного, воєнно-економічного та науково-технічного розвитку України, а також ефективних механізмів концентрації ресурсів для досягнення таких цілей є також загрозою національній безпеці України. У зв’язку з цим існує нагальна потреба комплексного теоретико-методологічного аналізу системи державного стратегічного планування в сфері публічного управління, зокрема з використання провідного досвіду країна з різним рівнем розвитку ринкових відносин [7].

Висновки. Таким чином, узагальнення точок зору зарубіжних і вітчизняних авторів на сучасні механізми та інструменти стратегічного планування та управління показало, що загострюючи увагу на характерні зв'язки держави 3 чисельними факторами внутрішнього та зовнішнього середовища, стратегічний і ситуаційний підхід є на сьогодні продовженням та розвитком системного підходу, передовим підходом в управлінському мисленні і стратегічному плануванні. Повернення до ситуаційного підходу при публічному та особливо регіональному управлінні, виробленні суб'єктами управління організаційних механізмів адаптації до децентралізованих умов розвитку дозволить успішно i результативне упоратися із наявними господарськими, ресурсними та економічними проблемами і досягти конкурентних переваг на національному та світовому ринках

\section{Список використаних джерел:}

1. Про затвердження Державної стратегї̈ регіонального розвитку на 20212027 роки / https://zakon.rada.gov.ua/laws/show/695-2020-\%D0\%BF\#Text.

2. Воротін В. Є. Модернізація сфери освіти та науки як об'єкта державного управління: конкурентні переваги для України / В.С. Воротін // Наукові записки Інституту законодавства Верховної Ради України. 2017. № 6. С. 153-160.

3. Инструментарий для оценки воздействия на конкуренцию. Том II: Руководство / OECD. URL: http://www.oecd.org/daf/ competition/49167929.pdf.

4. Воротін В. С., Проданик В. М. Від регуляторної політики до державноприватного партнерства в публічному секторі України. / В.С Воротін, В.М. 
Проданик // Наукові записки Інституту законодавства Верховної Ради України. 2019. № 1. C. 95-102.

5. Evaluating laws, policies and funding programmes / European Commission. URL: https://ec.europa.eu/info/law/law-making- process/evaluating-andimproving-existing- laws/evaluating-laws_en.

6. Антикризове управління національною економікою : монографія / [I. Малий, І. Радіонова, А. Ємельянов та ін.]; за заг. ред. І. Малого. К. : КНЕУ. 2017. $368 \mathrm{c}$.

7. Воротін В. Є., Шевченко А.В. Підтримка міждержавного регіонального співробітництва: інституційні перспективи розвитку єврорегіонів/ В.С Воротін, А.В. Шевченко // Науковий вісник: державне управління: журнал. 2020. №3 (5) 2020. C. 22-34.

\section{References:}

1. Pro zatverdzhennia Derzhavnoi stratehii rehionalnoho rozvytku na 20212027 roky / https://zakon.rada.gov.ua/laws/show/695-2020-\%D0\%BF\#Text.

2. Vorotin V. Ye. Modernizatsiia sfery osvity ta nauky yak obiekta derzhavnoho upravlinnia: konkurentni perevahy dlia Ukrainy / V.Ye. Vorotin // Naukovi zapysky Instytutu zakonodavstva Verkhovnoi Rady Ukrainy. 2017. № 6. P. 153-160 [in Ukrainian].

3. Ynstrumentaryi dlia otsenky vozdeistvyia na konkurentsyiu. Tom II: Rukovodstvo / OECD. URL: http://www.oecd.org/daf/ competition/49167929.pdf

4. Vorotin V. Ye., Prodanyk V. M. Vid rehuliatornoi polityky do derzhavnopryvatnoho partnerstva $\mathrm{v}$ publichnomu sektori Ukrainy. / V.Ye Vorotin, V.M. Prodanyk // Naukovi zapysky Instytutu zakonodavstva Verkhovnoi Rady Ukrainy. 2019. № 1. P. 95-102 [in Ukrainian].

5. Evaluating laws, policies and funding programmes / European Commission. URL: https://ec.europa.eu/info/law/law-making- process/evaluating-andimproving-existing- laws/evaluating-laws_en.

6. Antykryzove upravlinnia natsionalnoiu ekonomikoiu : monohrafiia / [I. Malyi, I. Radionova, A. Yemelianov ta in.]; za zah. red. I. Maloho. K. : KNEU. 2017. 368 p [in Ukrainian].

7. Vorotin V. Ye., Shevchenko A.V. Pidtrymka mizhderzhavnoho rehionalnoho spivrobitnytstva: instytutsiini perspektyvy rozvytku yevrorehioniv / V.Ye Vorotin, A.V. Shevchenko // Naukovyi visnyk: derzhavne upravlinnia: zhurnal. 2020. №3 (5) 2020. P. 22-34 [in Ukrainian]. 